\title{
Matrix-precipitation for the Determination of Trace Impurities in High-purity Iron
}

\author{
Hiroaki MATSUMIYA, ${ }^{1 / *}$ Masahiro KUROMIYA ${ }^{2)}$ and Masataka HIRAIDE ${ }^{2)}$ \\ 1) Division of Environmental Research, EcoTopia Science Institute, Nagoya University, Furo-cho, Chikusa-ku, Nagoya, 464- \\ 8603 Japan. $\quad$ 2) Department of Molecular Design and Engineering, Graduate School of Engineering, Nagoya University, \\ Furo-cho, Chikusa-ku, Nagoya, 464-8603 Japan.
}

(Received on June 14, 2012; accepted on September 25, 2012)

\begin{abstract}
The present paper describes a facile method for the determination of trace impurities in iron metals. This method is based on the selective removal of the matrix element as hydroxide precipitate followed by the determination of desired trace elements left in the solution. To an iron sample solution were added ethylene glycol bis(2-aminoethyl ether)- $N, N, N^{\prime}, N^{\prime}$-tetraacetic acid (EGTA) and diethylenetriamine. The iron(III) matrix was almost completely (>99\%) precipitated at pH 9.5, while trace elements [Mn(II), Co(II), $\mathrm{Ni}(I I), \mathrm{Cu}(\mathrm{II}), \mathrm{Zn}(\mathrm{II}), \mathrm{Cd}(\mathrm{II})$, and $\mathrm{Pb}(\mathrm{II})]$ were left in the solution due to the complexation with EGTA and diethylenetriamine. The sufficient removal of the matrix element and negligible loss of trace elements allowed the sensitive determination at $\mathrm{ng} \mathrm{g}^{-1}$ levels by inductively coupled plasma-mass spectrometry.
\end{abstract}

KEY WORDS: matrix precipitation; iron(III) hydroxide; trace metals; high-purity iron; inductively coupled plasma-mass spectrometry.

\section{Introduction}

Iron metals are essential materials in various fields of industry. The properties of iron metals strongly depend on the impurities, even at low $\mu \mathrm{g} \mathrm{g}^{-1}$ or lower levels. ${ }^{1,2)}$ The analysis for trace impurities is thus important for the quality control and gaining further insight into the synergistic action and correlation of the impurities. Ishida and colleagues obtained the detection limits at $10 \mathrm{ng} \mathrm{g}^{-1}$ levels by the combination of laser ablation and inductively coupled plasma-mass spectrometry (ICP-MS). ${ }^{3)}$ Difficulties in the direct analysis include heterogeneous ablation, insufficient introduction of ablated particles, and serious matrix-interferences. Therefore, trace analysis of high-purity iron metals generally requires chemical pretreatment steps, ${ }^{4)}$ in which the desired elements are separated from the matrix element to obtain accurate and precise results.

Many separation techniques, including sorption, ${ }^{5-12)}$ liquidliquid extraction, ${ }^{13-18)}$ coprecipitation, ${ }^{18-22)}$ electrolysis, ${ }^{14,23,24)}$ and volatilization, ${ }^{25,26)}$ have been employed to determine impurities at ultratrace levels in iron and steels. However, these techniques are often tedious and time-consuming and they sometimes require volatile, flammable, and ill-smelling organic solvents or corrosive and hazardous acids. Special instruments are also needed for some techniques. The authors have therefore developed multielement separation techniques based on the selective removal of an iron(III) matrix with polyoxyethylene-type nonionic surfactants. ${ }^{9,16)}$ The sufficient removal was attained at high concentrations

* Corresponding author: E-mail: h-matsu@numse.nagoya-u.ac.jp DOI: http://dx.doi.org/10.2355/isijinternational.53.81 of hydrochloric acid or lithium chloride, while various trace elements were left in the solution and determined by ICPMS. Before the determination, however, the evaporation of the solution or the sorption and desorption of trace elements were required to eliminate the excess acid or salt, respectively.

Alternatively, selective precipitation of the matrix element, though scarcely applied to iron samples, is potentially useful for facile multielement separation. The determination of trace elements left in the solution can facilitate the trace analysis of several materials (e.g., copper, silver, and lead metals) for impurities. ${ }^{27-29)}$ However, the coprecipitation loss of trace elements is often problematic for iron samples. For example, Watanabe and colleagues removed the iron(III) matrix as hydroxide precipitate to determine $\mathrm{Cr}$ in steel. ${ }^{30)}$ The recovery was not quantitative $(84 \%)$ due to the coprecipitation, though the removal was satisfactory. Other elements such as $\mathrm{Mn}(\mathrm{II}), \mathrm{Ni}(\mathrm{II})$, and $\mathrm{Cu}(\mathrm{II})$ were almost completely coprecipitated.

In the present study, coprecipitation of trace elements was successfully controlled by complexation. The iron(III) matrix was selectively precipitated as the hydroxide, leaving trace elements [Mn(II), $\mathrm{Co}(\mathrm{II}), \mathrm{Ni}(\mathrm{II}), \mathrm{Cu}(\mathrm{II}), \mathrm{Zn}(\mathrm{II}), \mathrm{Cd}(\mathrm{II})$, and $\mathrm{Pb}(\mathrm{II})]$ in the solution. The direct analysis of the supernatant solution by ICP-MS offered the determination of impurities even at $\mathrm{ng} \mathrm{g}^{-1}$ levels in iron metals. The proposed separation method is simple and rapid and it employs no special instrument. 


\section{Experimental}

\subsection{Apparatus and Reagents}

An SPQ-6500 ICP-mass spectrometer (without a dynamic reaction cell, Seiko Instruments and Electronics, Ltd.) and an AA-1 Mark II atomic absorption spectrometer (Nippon Jarrell-Ash Co., Ltd.) were used for the determination of trace metals and iron, respectively. The operating conditions are summarized in Table 1. An MX-300 centrifuge (Tomy Digital Biology Co., Ltd.) was used for the separation of hydroxide precipitate at $7000 \mathrm{~g}$.

Ethylenediamine, diethylenetriamine, triethylenetetramine, and tetraethylenepentamine (Kishida Chemical Co., Ltd.) were dissolved each in water to give a concentration of 4.0 M. Aqueous 28\% (w/w) ammonia (Wako Pure Chemical Industries, Ltd.) and 25\% (w/w) tetramethylammonium hydroxide (TMAH, ultra-pure grade, Tama Chemicals Co., Ltd.) were diluted with water to appropriate concentrations. Iminodiacetic acid (IDA), nitrilotriacetic acid (NTA), ethylenediamine- $N, N, N^{\prime}, N^{\prime}$-tetraacetic acid (EDTA), ethylene glycol bis(2-aminoethyl ether)- $N, N, N^{\prime}, N^{\prime}$-tetraacetic acid (EGTA), and diethylenetriamine- $N, N, N$ ', $N$ ", $N$ "'-pentaacetic acid (DTPA) (Dojindo Laboratories) were dissolved each in a $2.5 \%(\mathrm{w} / \mathrm{w})$ TMAH solution to give a concentration of $0.10 \mathrm{M}$.

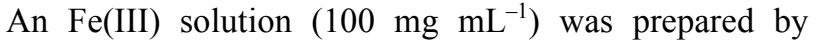
decomposing $2.00 \mathrm{~g}$ of iron metal (99.998\% purity, powder, Johnson Matthey Plc) with $6.0 \mathrm{~mL}$ each of $12 \mathrm{M} \mathrm{HCl}$ and $16 \mathrm{M} \mathrm{HNO}_{3}$ at $60-70^{\circ} \mathrm{C}$ and diluting the solution to $20 \mathrm{~mL}$ with water. Certified reference materials (CRM) for highpurity iron, JSS 001-6 and JSS 003-5 (chips), were obtained from Japan Iron and Steel Federation. Another CRM for high-purity iron, NIST 2168 (chips), was obtained from National Institute of Standards and Technology. Standard solutions of metals $\left(1.0 \mu \mathrm{g} \mathrm{mL}^{-1}\right.$ in $\left.1.0 \mathrm{M} \mathrm{HNO}_{3}\right)$ were prepared from commercial standard solutions (Wako Pure Chemical Industries, Ltd.). Mineral acids included nitric acid (16 M, ultra-pure grade, Kanto Chemical Co., Inc.) and

Table 1. Operating conditions for ICP-MS and atomic absorption spectrometry.

\section{ICP-MS}

Argon flow rate

$$
\text { Outer }
$$$$
17 \mathrm{~L} \mathrm{~min}^{-1}
$$

Intermediate

$0.8 \mathrm{~L} \mathrm{~min}^{-1}$

Carrier

$$
1.0 \mathrm{~L} \mathrm{~min}^{-1}
$$

RF power

$0.8 \mathrm{~kW}$

Sampling depth

\section{$12 \mathrm{~mm}$}

Isotopes measured

$$
{ }^{55} \mathrm{Mn},{ }^{59} \mathrm{Co},{ }^{60} \mathrm{Ni},{ }^{63} \mathrm{Cu},{ }^{64} \mathrm{Zn},{ }^{114} \mathrm{Cd},{ }^{208} \mathrm{~Pb}
$$

Atomic absorption spectrometry

Flame gas flow rate

$\begin{array}{cl}\text { Air } & 7.0 \mathrm{~L} \mathrm{~min}^{-1} \\ \text { Acetylene } & 2.0 \mathrm{~L} \mathrm{~min}^{-1} \\ \text { Lamp current } & 10 \mathrm{~mA} \\ \text { Wavelength measured } & 248.3 \mathrm{~nm}(\mathrm{Fe})\end{array}$

hydrochloric acid (12 M, ultra-pure grade, Kanto Chemical Co., Inc.).

All reagents used were of reagent grade, unless otherwise stated. Water was purified with a Milli-Q Gradient A-10 system (Nihon Millipore K. K.).

\subsection{Recommended Procedure}

A 1.00 -g iron sample was decomposed with $3.0 \mathrm{~mL}$ each of $12 \mathrm{M} \mathrm{HCl}$ and $16 \mathrm{M} \mathrm{HNO}_{3}$ at $60-70^{\circ} \mathrm{C}$ and diluted to 10 $\mathrm{mL}$ with water. A $1 / 20$-aliquot ( $50 \mathrm{mg}$ as $\mathrm{Fe}$ ) of the solution was taken in a $15-\mathrm{mL}$ centrifugation tube and diluted to 2.5 $\mathrm{mL}$ with water. After adding $1.25 \mathrm{~mL}$ of EGTA solution, the solution was mixed with $0.88 \mathrm{~mL}$ of diethylenetriamine solution to adjust the $\mathrm{pH}$ to 9.5 (if necessary, TMAH solution was further added). The solution was diluted to $5.0 \mathrm{~mL}$ with water, left to stand for $10 \mathrm{~min}$, and centrifuged for 5 min to separate the precipitate of iron(III) hydroxide. The supernatant solution was analyzed by ICP-MS for trace metals. Calibration graphs were constructed as follows. In a 5.0$\mathrm{mL}$ volumetric flask were taken $0.80 \mathrm{~mL}$ of $5 \mathrm{M} \mathrm{HNO}_{3}, 1.25$ $\mathrm{mL}$ of EGTA solution, and $0.88 \mathrm{~mL}$ of diethylenetriamine solution. After adding metals of interest at $\mathrm{pg} \mathrm{mL}^{-1}$ to $\mathrm{ng}$ $\mathrm{mL}^{-1}$ levels, the solution was diluted to the mark with water and introduced into the ICP-mass spectrometer.

\section{Results and Discussion}

\subsection{Control of Coprecipitation by Complexation}

First, the coprecipitation of trace metals was investigated with $5.0 \mathrm{~mL}$ of sample solution containing $50 \mathrm{mg}$ of iron(III) and $250 \mathrm{ng}$ each of $\mathrm{Mn}(\mathrm{II}), \mathrm{Co}(\mathrm{II}), \mathrm{Ni}(\mathrm{II}), \mathrm{Cu}(\mathrm{II})$, $\mathrm{Zn}(\mathrm{II}), \mathrm{Cd}(\mathrm{II})$, and $\mathrm{Pb}(\mathrm{II})$. The $\mathrm{pH}$ was adjusted to 9.5 with an alkaline reagent TMAH to form the precipitate of iron(III) hydroxide. The iron and trace metals left in the solution were determined by atomic absorption spectrometry and ICP-MS, respectively. The iron was found to be $0.012 \mathrm{mg}$ (99.98\% removal), which did not interfere with ICP-MS. The trace metals, however, were less than $10 \mathrm{ng}$, which indicates that more than $96 \%$ of trace metals were lost by coprecipitation.

The loss of trace metals was partly prevented by adding an aminopolycarboxylate ligand before the precipitation. As given in Table 2, the losses of $\mathrm{Cu}$ and $\mathrm{Cd}$ were nearly negligible with EDTA, EGTA, and DTPA, while the other metals were still lost and insufficiently left in the solution. On the other hand, the removal of the iron matrix was interfered

\begin{tabular}{|c|c|c|c|c|c|c|c|c|}
\hline & \multicolumn{7}{|c|}{ Trace metals recovered, $\%$} & \multirow{2}{*}{$\begin{array}{l}\mathrm{Fe} \\
\text { remaining/ } \\
\mathrm{mg}\end{array}$} \\
\hline & $\mathrm{Mn}$ & Co & $\mathrm{Ni}$ & $\mathrm{Cu}$ & $\mathrm{Zn}$ & $\mathrm{Cd}$ & $\mathrm{Pb}$ & \\
\hline IDA & 0 & 55 & 66 & 69 & 0 & 1 & 8 & 0.0066 \\
\hline NTA & 28 & 54 & 52 & 76 & 68 & 88 & 3 & 0.68 \\
\hline EDTA & 73 & 81 & 42 & 93 & 96 & 92 & 82 & 7.3 \\
\hline EGTA & 64 & 68 & 62 & 96 & 62 & 97 & 52 & 0.011 \\
\hline DTPA & 69 & 66 & 64 & 91 & 92 & 91 & 73 & 7.1 \\
\hline
\end{tabular}

Table 2. Separation of trace metals with different aminopolycarboxylate ligands.

Trace metals $250 \mathrm{ng}$ each, Fe $50 \mathrm{mg}$, aminopolycarboxylate ligand $25 \mathrm{mM}$, pH 9.5. 
by the complexation with aminopolycarboxylate ligands, except for IDA and EGTA. Compared with IDA, EGTA was more powerful in controlling the coprecipitation, hence it was used in the following studies.

To completely control the coprecipitation, the $\mathrm{pH}$ was adjusted with an amine ligand, instead of TMAH, after the addition of EGTA. As given in Table 3, diethylenetriamine and tetraethylenepentamine were effective for all the trace metals tested. However, the latter was more reactive with iron than the former, leading to the one order of magnitude decrease in the removal efficiency. Therefore, the former was used together with EGTA. The iron remaining in the solution $\left(0.13 \mathrm{mg}\right.$, or $\left.26 \mu \mathrm{g} \mathrm{mL}^{-1}\right)$ did not interfere with ICP-MS.

\subsection{Effect of Ligand Concentration and $\mathbf{p H}$}

The combination of EGTA and diethylenetriamine met the criteria of removing the iron matrix and leaving trace metals in the solution. The effect of the EGTA concentration was next investigated at a diethylenetriamine concentration of $0.70 \mathrm{M}$ and $\mathrm{pH} 9.5$ (optimal conditions, as described later). As given in Table 4, the appreciable loss of $\mathrm{Pb}$ was observed at 10 and $20 \mathrm{mM}$. On the other hand, the removal of the iron matrix was deteriorated at $30 \mathrm{mM}$ because the unfavorable complexation with EGTA became not negligible. Holding the EGTA concentration constant $(25 \mathrm{mM}$, optimal condition), the effect of the amine concentration was investigated. Because the $\mathrm{pH}$ varied with the amine

Table 3. Separation of trace metals with EGTA and different amine ligands.

\begin{tabular}{|c|c|c|c|c|c|c|c|c|}
\hline & \multicolumn{7}{|c|}{ Trace metals recovered, $\%$} & \multirow{2}{*}{$\begin{array}{l}\mathrm{Fe} \\
\text { remaining/ } \\
\mathrm{mg}\end{array}$} \\
\hline & Mn & Co & $\mathrm{Ni}$ & $\mathrm{Cu}$ & $\mathrm{Zn}$ & $\mathrm{Cd}$ & $\mathrm{Pb}$ & \\
\hline Ammonia & 82 & 78 & 79 & 103 & 86 & 103 & 88 & 0.015 \\
\hline Ethylenediamine & 101 & 84 & 106 & 101 & 96 & 104 & 94 & 0.019 \\
\hline Diethylenetriamine & 98 & 95 & 97 & 103 & 99 & 98 & 100 & 0.13 \\
\hline Triethylenetetramine & 100 & 73 & 98 & 104 & 95 & 98 & 96 & 1.1 \\
\hline Tetraethylenepentamine & 103 & 97 & 94 & 99 & 96 & 95 & 96 & 1.0 \\
\hline
\end{tabular}

Trace metals $250 \mathrm{ng}$ each, Fe $50 \mathrm{mg}$, EGTA $25 \mathrm{mM}$, amine ligand $0.70 \mathrm{M}$, $\mathrm{pH} 9.5$. concentration, it was maintained at 9.5 by further adding TMAH or nitric acid, if necessary. As given in Table 4, the lower concentrations $(0.20$ and $0.40 \mathrm{M})$ led to the loss of $\mathrm{Mn}, \mathrm{Co}, \mathrm{Zn}$, and $\mathrm{Pb}$, while the higher concentrations $(0.80$ and $0.90 \mathrm{M}$ ) resulted in the gradual decrease in the removal efficiency for the iron matrix. Considering the results of the series of experiments, $25 \mathrm{mM}$ EGTA and $0.70 \mathrm{M}$ diethylenetriamine were employed in the following studies.

The effect of $\mathrm{pH}$ was shown in Fig. 1. The loss of trace
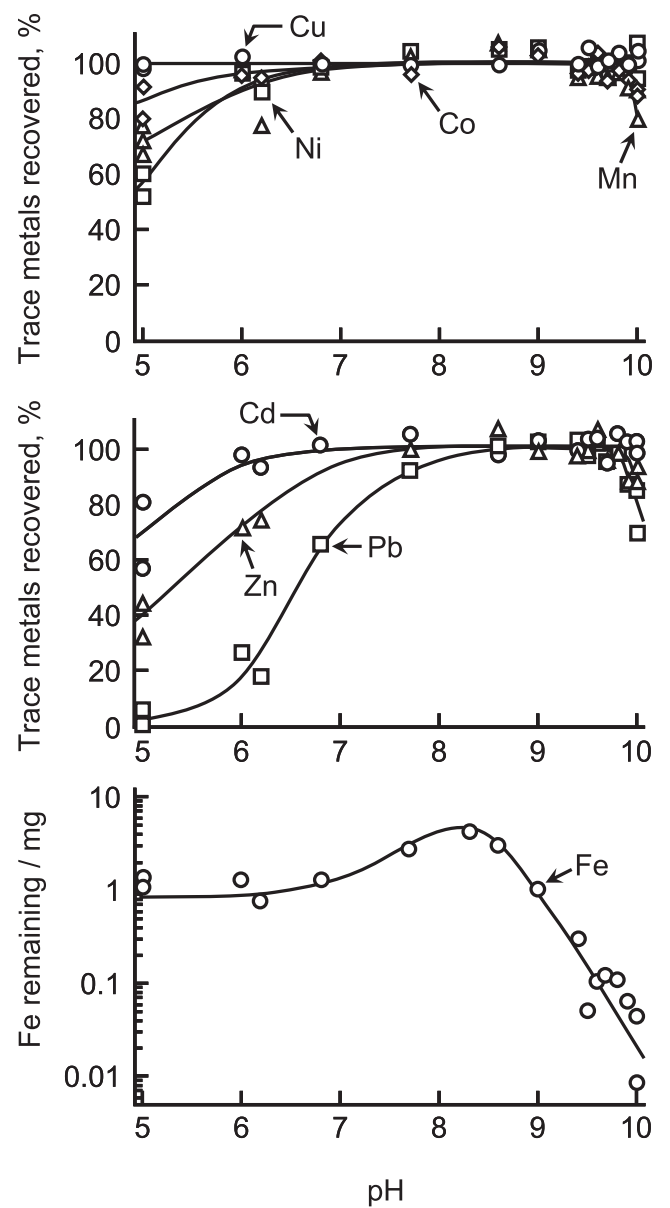

Fig. 1. Effect of $\mathrm{pH}$ on the separation of trace metals from iron matrix. Trace metals $250 \mathrm{ng}$ each, Fe $50 \mathrm{mg}$, EGTA 25 $\mathrm{mM}$, diethylenetriamine $0.70 \mathrm{M}$.

Table 4. Effect of the ligand concentration on the separation efficiency.

\begin{tabular}{|c|c|c|c|c|c|c|c|c|c|}
\hline \multirow{2}{*}{$\begin{array}{c}\text { EGTA } \\
\text { added/ } \\
\mathrm{mM}\end{array}$} & \multirow{2}{*}{$\begin{array}{l}\text { Diethylene- } \\
\text { triamine } \\
\text { added/M }\end{array}$} & \multicolumn{7}{|c|}{ Trace metals recovered, $\%$} & \multirow{2}{*}{$\begin{array}{c}\mathrm{Fe} \\
\text { remaining/ } \\
\mathrm{mg}\end{array}$} \\
\hline & & $\mathrm{Mn}$ & $\mathrm{Co}$ & $\mathrm{Ni}$ & $\mathrm{Cu}$ & $\mathrm{Zn}$ & $\mathrm{Cd}$ & $\mathrm{Pb}$ & \\
\hline 10 & 0.70 & 91 & 96 & 102 & 102 & 95 & 97 & 75 & 0.032 \\
\hline 20 & 0.70 & 100 & 96 & 99 & 103 & 96 & 104 & 87 & 0.042 \\
\hline \multirow[t]{6}{*}{25} & 0.20 & 82 & 82 & 96 & 98 & 89 & 103 & 72 & 0.038 \\
\hline & 0.40 & 87 & 91 & 95 & 97 & 90 & 96 & 81 & 0.094 \\
\hline & 0.60 & 97 & 98 & 97 & 100 & 96 & 100 & 99 & 0.11 \\
\hline & 0.70 & 100,102 & 97,97 & 100,103 & 99,104 & 102,104 & 99,99 & 100,101 & $0.10,0.12$ \\
\hline & 0.80 & 96 & 97 & 95 & 99 & 100 & 101 & 100 & 0.29 \\
\hline & 0.90 & 100 & 99 & 95 & 101 & 96 & 101 & 96 & 0.47 \\
\hline 30 & 0.70 & 96 & 101 & 100 & 99 & 99 & 102 & 100 & 0.37 \\
\hline
\end{tabular}



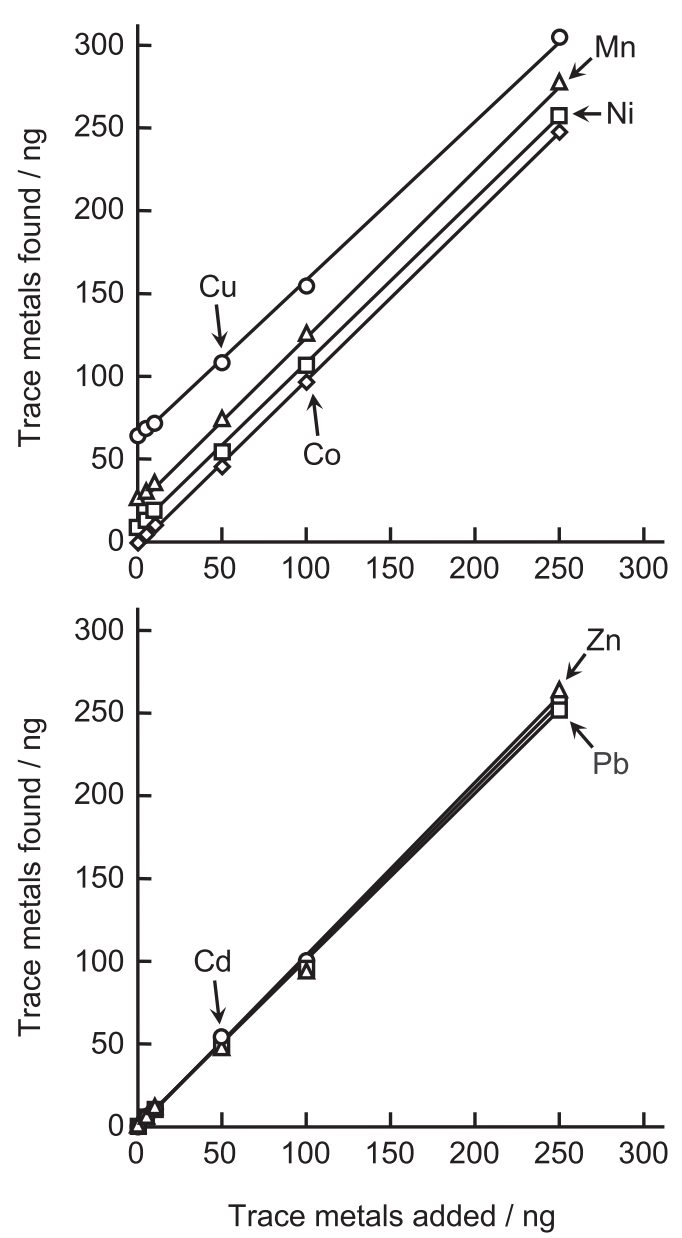

Fig. 2. Simultaneous separation of trace metals from $50 \mathrm{mg}$ of iron matrix.

metals was significant at lower pH's due to the insufficient complexation. The increase in $\mathrm{pH}$ made the complexation satisfactory and the coprecipitation was well controlled at pH 8.6-9.8 for all the trace metals tested. However, further increase in $\mathrm{pH}$ caused the modest loss of $\mathrm{Mn}, \mathrm{Co}, \mathrm{Zn}$, and $\mathrm{Pb}$ because their hydrolysis became gradually dominant. On the other hand, the amount of iron remaining in the solution peaked at $\mathrm{pH} 8.3$ and considerably decreased with increasing $\mathrm{pH}$. Because of the high reactivity of iron(III) toward hydroxide ions, ${ }^{31)}$ the hydrolysis would be overwhelming above $\mathrm{pH} 8.3$, providing the enhanced selectivity. The $\mathrm{pH}$ was fixed at 9.5 for the successful separation.

\subsection{Analysis of Synthetic and Real Samples}

A series of synthetic sample solutions was prepared to validate the proposed method at ultratrace levels. A highpurity iron metal was decomposed with a mixture of $\mathrm{HCl}$ and $\mathrm{HNO}_{3}$. Concentrated acids were used, otherwise a longer time was required for the complete decomposition. Heating at excessively higher temperatures sometimes produced the black residue, hence the temperature was controlled at $60-70^{\circ} \mathrm{C}$. Aliquots $(50 \mathrm{mg}$ as $\mathrm{Fe})$ of the resulting solution were mixed with the known amount of trace metals and treated by the proposed method. As shown in Fig. 2, the relations between the amounts of trace metals added and found showed good linearity with slopes of 0.96-1.05, indi-
Table 5. Analytical results for high-purity iron metals.

\begin{tabular}{|c|c|c|c|}
\hline \multirow{2}{*}{ Sample } & \multirow{2}{*}{ Metal } & \multicolumn{2}{|c|}{ Concentration in sample $/ \mu \mathrm{g} \mathrm{g}^{-1}$} \\
\hline & & Determined $^{a}$ & Certified \\
\hline \multirow[t]{7}{*}{ JSS 001-6 } & $\mathrm{Mn}$ & $0.03 \pm 0.03$ & $(0.03)^{b}$ \\
\hline & $\mathrm{Co}$ & $0.37 \pm 0.02$ & $0.32 \pm 0.05$ \\
\hline & $\mathrm{Ni}$ & $0.20 \pm 0.04$ & $(0.2)^{b}$ \\
\hline & $\mathrm{Cu}$ & $0.37 \pm 0.02$ & $0.36 \pm 0.05$ \\
\hline & $\mathrm{Zn}$ & $2.0 \pm 0.1$ & $1.9 \pm 0.3$ \\
\hline & $\mathrm{Cd}$ & $0.031 \pm 0.003$ & $-^{c}$ \\
\hline & $\mathrm{Pb}$ & $0.18 \pm 0.01$ & $0.18 \pm 0.02$ \\
\hline \multirow[t]{7}{*}{ JSS 003-5 } & $\mathrm{Mn}$ & $27 \pm 1$ & $27 \pm 1$ \\
\hline & $\mathrm{Co}$ & $2.0 \pm 0.1$ & $2.2 \pm 0.2$ \\
\hline & $\mathrm{Ni}$ & $0.38 \pm 0.02$ & $0.4 \pm 0.1$ \\
\hline & $\mathrm{Cu}$ & $16 \pm 1$ & $15.4 \pm 0.5$ \\
\hline & $\mathrm{Zn}$ & $<0.07$ & $(<0.5)^{b}$ \\
\hline & $\mathrm{Cd}$ & $<0.007$ & $(<0.1)^{b}$ \\
\hline & $\mathrm{Pb}$ & $<0.02$ & $(<0.1)^{b}$ \\
\hline \multirow[t]{7}{*}{ NIST 2168} & $\mathrm{Mn}$ & $4.6 \pm 0.2$ & $6 \pm 4$ \\
\hline & Co & $7.1 \pm 0.5$ & $6 \pm 2$ \\
\hline & $\mathrm{Ni}$ & $12 \pm 1$ & $10 \pm 5$ \\
\hline & $\mathrm{Cu}$ & $4.3 \pm 0.3$ & $5 \pm 2$ \\
\hline & $\mathrm{Zn}$ & $3.6 \pm 0.3$ & $(<5)^{b}$ \\
\hline & $\mathrm{Cd}$ & $0.022 \pm 0.004$ & $(<1)^{b}$ \\
\hline & $\mathrm{Pb}$ & $0.03 \pm 0.01$ & $(<1)^{b}$ \\
\hline
\end{tabular}

${ }^{a}$ Mean \pm standard deviation, $n=4$.

${ }^{b}$ Indicative value.

${ }^{c}$ Not given.

cating the nearly complete recovery. For $\mathrm{Mn}, \mathrm{Ni}$, and $\mathrm{Cu}$, the intercepts were not zero, which was ascribed to the trace impurities in the high-purity iron metal used. The concentrations (in $\mu \mathrm{g} \mathrm{g}^{-1}$ ) were calculated to be $0.46(\mathrm{Mn}), 0.17$ (Ni), and $1.3(\mathrm{Cu})$.

Finally, certified reference materials for high-purity iron (JSS 001-6, JSS 003-5, and NIST 2168) were analyzed. As given in Table 5, trace impurities at low $\mu \mathrm{g} \mathrm{g}^{-1}$ to $\mathrm{ng} \mathrm{g}^{-1}$ levels were successfully determined. The obtained values were almost consistent with the certified or indicative values. The blank values through the whole procedure were $0.43 \pm 0.04$ $\mu \mathrm{g} \mathrm{g}^{-1}$ (mean \pm standard deviation, $n=6$ ) for $\mathrm{Cu}$ and undetectable for the other metals. The detection limits $\left(\mu \mathrm{g} \mathrm{g}^{-1}\right)$ based on the $3 \sigma$ blank fluctuations were $0.02(\mathrm{Mn}, \mathrm{Co}, \mathrm{Ni}$, and $\mathrm{Pb}), 0.2(\mathrm{Cu}), 0.07(\mathrm{Zn})$, and $0.007(\mathrm{Cd})$. The proposed method is simple and rapid, and it would provide useful information for the quality control of high-purity iron metals and better understanding of the behavior of impurities at ultratrace levels.

\section{REFERENCES}

1) H. Kimura: ISIJ Int., 34 (1994), 225.

2) K. Abiko: Phys. Stat. Sol. A, 160 (1997), 285.

3) T. Ishida, A. Akiyoshi, A. Sakashita, S. Kinoshiro, K. Fujimoto and 
A. Chino: Bunseki Kagaku, 55 (2006), 229.

4) H. Matsumiya and M. Hiraide: Tetsu-to-Hagané, 97 (2011), 36.

5) A. G. Coedo, T. D. López and F. Alguacil: Anal. Chim. Acta, 315 (1995), 331.

6) S. Hasegawa, K. Sato, K. Ide, T. Kobayashi, S. Igarashi and K. Naito: J. Jpn. Inst. Met., 64 (2000), 1212.

7) K. Fujimoto and M. Shimura: Bunseki Kagaku, 50 (2001), 175

8) K. Fujimoto, M. Shimura and S. Satoh: Mater. Trans., 43 (2002), 101.

9) H. Matsumiya, S. Furuzawa and M. Hiraide: Anal. Chem., 77 (2005), 5344.

10) Y. Xu, J. Zhou, G. Wang, J. Zhou and G. Tao: Anal. Chim. Acta, 584 (2007), 204.

11) H. Matsumiya, T. Kikai and M. Hiraide: Anal. Sci., 25 (2009), 207.

12) N. Uehara: Tetsu-to-Hagané, 97 (2011), 54.

13) J. S. Chen, H. Berndt, R. Klockenkämper and G. Tölg: Fresenius J. Anal. Chem., 338 (1990), 891.

14) A. G. Coedo, M. T. Dorado and I. Padilla: Spectrochim. Acta B, 60 (2005), 73.

15) H. Matsumiya and M. Hiraide: Tetsu-to-Hagané, 93 (2007), 85.

16) H. Matsumiya, Y. Sakane and M. Hiraide: Anal. Chim. Acta, 653 (2009), 86.

17) H. Matsumiya, Y. Inagaki and M. Hiraide: ISIJ Int., 52 (2012), 101

18) K. Takada: Phys. Stat. Sol. A, 160 (1997), 561.

19) T. Ashino, K. Takada and K. Hirokawa: Anal. Chim. Acta, 297
(1994), 443

20) Y. Danzaki: Fresenius J. Anal. Chem., 356 (1996), 143.

21) S. Kagaya, K. Kakehashi and K. Hasegawa: Tetsu-to-Hagané, 93 (2007), 80

22) T. Itagaki, T. Ashino, K. Takada and K. Wagatsuma: Bunseki Kagaku, 59 (2010), 43

23) M. Hiraide, P. Tschöpel and G. Tölg: Anal. Chim. Acta, 186 (1986), 261.

24) A. G. Coedo, I. Padilla, T. Dorado and F. J. Alguacil: Anal. Chim. Acta, 389 (1999), 247.

25) X. Duan, R. L. McLaughlin, I. D. Brindle and A. Conn: J. Anal. At. Spectrom., 17 (2002), 227.

26) A. Matsumoto and T. Nakahara: Tetsu-to-Hagané, 91 (2005), 505.

27) J. Minczewski, J. Chwastowska and R. Dybczyñski: Separation and Preconcentration Methods in Inorganic Trace Analysis, Ellis Horwood, Chichester, (1982), 42.

28) A. Mizuike: Enrichment Techniques for Inorganic Trace Analysis, Springer-Verlag, Berlin, (1983), 56.

29) Yu. A. Zolotov and N. M. Kuz'min: Preconcentration of Trace Elements, Elsevier, Amsterdam, (1990), 80.

30) K. Watanabe, M. Akiyama, I. Shitanda and M. Itagaki: Bunseki Kagaku, 58 (2009), 873.

31) C. F. Baes, Jr. and R. E. Mesmer: The Hydrolysis of Cations, Wiley, New York, (1976), 229. 